\title{
ENDOVASCULAR EMBOLIZATION OF CEREBRAL ARTERIOVENOUS MALFORMATIONS
}

Sarhan AA; Aidaros MA; Sobh KM* and El-Serafy TSS

Neurology Department, Faculty of Medicine, Zagazig and Al-Azhar* Universities

ABSTRACT
Background: An arteriovenous malformation is a collection of dysplsatic plexiform vessels that is supplied
by one or more arterial feeders and drained by one or more venous channels. Arteriovenous malformations
may have a pure plexiform nidus or contain a mixed plexiform fistulous nidus. Objective: This work was
carried out to evaluate the clinical outcome and effectiveness of the endovascular treatment of cerebral
arteriovenous malformations with ethylene vinyl alcohol copolymer (Onyx). Methods: Twenty five patients
(14 males and 11 females) with cerebral arteriovenous malformations were treated by embolization with
Onyx at the Neurointervention Unit in Al-Azhar University. All patients with intracranial AVMs were
subjected to preprocedural, procedural and postprocedural assessments. Result(s): There was significant
difference in nidus diameter in all patients after embolization in comparison to before embolization. There
was significant difference in Spetzler and Martin grading system before and after embolization.
Conclusion(s): Onyx as a new embolic material, with its non-adherent properties has significantly facilitated
this development.
Key Words: endovascular, cerebral, arteriovenous malformation, Onyx

\section{INTRODUCTION}

B rain anteriovenous malformations (AVMs) are complex vascular lesions in which arterial blood flow, directly into draining veins without an intervening capillary bed, through a venous conglomerate called nidus. As a consequence, blood flow is unregulated and pressure within the nidus rises exposing the veins to very high pressures $^{(\mathbf{1})}$.

The arteriovenous malformation detection rate is 1.1-1.2/100,000 persons/year and the incidence of arteriovenous malformation hemorrhage is $0.42 / 100,000$ persons/year ${ }^{(2)}$.

Spetzler and Martin ${ }^{(3)}$ proposed a simplified grading system based on the AVMS size, the eloquence of adjacent brain parenchyma and the venous drainage pattern. The AVMS size was divided into three categories: small $(<3 \mathrm{~cm})$, medium ( 3 to $6 \mathrm{~cm})$, and large $(>6 \mathrm{~cm})$.

An AVM was considered to be adjacent to eloquent brain parenchyma if it was next to sensorimotor cortex, language areas, visual cortex, hypothalamus, thalamus, internal capsule, brainstem, cerebellar peduncles, or deep cerebellar nuclei.

The venous drainage was designated as superficial if all of the venous drainage emptied into the cortical venous system. If any or all of the venous drainage emptied through deep veins (internal cerebral vein, basal veins and paracentral cerebellar veins), it was categorized as deep ${ }^{(3)}$.

Traditionally, most AVMs come into clinical attention because of hemorrhage, with epilepsy coming far behind as the second most common type of presentation. However, this pattern is gradually changing. Increasing availability of noninvasive imaging methods, mainly MRI, have led to more and more frequent detection of unruptured and even incidental $\mathrm{AVMs}^{(4)}$.

Cerebral arteriovenous malformations are amenable to various treatment modalities which include the following either individually or in combination: surgical removal (resection), radiosurgery and endovascular embolization ${ }^{(5)}$.

Endovascular embolization can be used for a curative embolization, nidus reduction before surgery or radiosurgery and palliative embolization. The goal of curative embolization is the complete and permanent obliteration of the AVMs nidus with the restoration of the normal arterial blood flow and the preservation of venous drainage $^{(6)}$.

The most commonly used embolic agent is the rapidly polymerizing liquid embolic agent $n$ Butyl Cyano-Acrylate (nBCA). The use of nBCA for brain AVMs requires experience and skill, because of the intra-nidal flow and polymerization of nBCA are both quick and largely unpredictable ${ }^{(7)}$.

After the introduction of the Onyx liquid embolic system $\left(\mathrm{EV}_{3}\right.$, Irvine, $\left.\mathrm{CA}\right)$ which is less adhesive, more slowly polymerizing and accordingly much more advantageous than $\mathrm{nBCA}$, $\mathrm{nBCA}$ was largely replaced as an agent for AVMs embolization $^{(8)}$.

\section{PATIENTS AND METHODS}

Between October 2010 and February 2013, twenty five patients (14 males and 11 females) with cerebral arteriovenous malformations were treated by embolization with Onyx at the Neurointervention Unit in Al-Azhar University.

\section{Inclusion criteria:}

- Compact AVMS. 
- The nidus was accessible with tip of the catheter.

- Low flow rate according to the four-vessel angiography.

- Patient not fit for other modality.

\section{Exclusion criteria:}

- High flow cerebral AVMS.

- Small superficial cerebral AVMS located in a surgically accessible non-eloquent area.

- Patient with contraindication to radiographic contrast.

- Complicated vascular anatomy.

- Poor medical conditions that cannot withstand multiple sessions.

- Patient refusing embolization.

All patients with intracranial AVMs were subjected to preprocedural, procedural and postprocedural assessments.

Preprocedural assessment:

- Complete medical history.

- Complete general and neurological examinations.

- Laboratory investigations with stressing on complete blood picture, coagulation profile, hepatitis markers, liver function tests and renal function tests.

- Radiological investigations:

CT (with and without contrast) was done for all patients for diagnosis after the presentation as an investigative study, for localization of the site of the AVMS, associated infarction or hydrocephalus.

MRI and MRA were done for all patients and were used as good diagnostic tools in revealing pathological anatomy, edema, gliosis and associated venous varix and nidal aneurysm.

$$
\text { Intra-Arterial Digital Subtraction }
$$
Angiography (IA-DSA).

CTA was available in some patients and not in others where it was replaced by IA-DSA.

\section{Procedure:}

An informed written consent was obtained from all patients. General anaesthesia was used in all patients. All sessions of Onyx embolization were carried out on a biplane angiographic unit.

A 6-French $(6 \mathrm{~F})$ arterial sheath was placed in the right femoral artery. Diagnostic cerebral angiography was performed and a $6 \mathrm{~F}$ guiding catheter was then inserted in either an internal carotid artery or a dominant vertebrtal artery using a standard co-axial technique.

A Dimethylsulphoxide (DMSO) compatible flow directed microcatheter (Marthon, CV3 Neurovascular) was navigated to the nidus of
AVMS with an aid of 0.008-inch guide wire (Mirage, ev3 Neurovascular).

Angiography was performed to ensure that the feeding pedicle could be occluded up to $2 \mathrm{~cm}$ retrogradely by the reflux of Onyx along the microcatheter.

The Onyx solution must be vigorously shaken for 20 minutes to fully suspend the micronized tantalum powder. Mixing is continued until just before the embolization. Failure to do this may result in inadequate radiopacity. The microcatheter was flushed with normal saline and the dead space was loaded with pure DMSO solvent.

The Onyx mixture was drawn into a DMSO compatible $1 \mathrm{cc}$ syringe. The syringe was connected to the microcatheter and a slow steady injection was began at a rate of $0.25 \mathrm{ml} / 90$ seconds to displace the DMSO in the dead space with Onyx.

The Onyx was slowly and progressively injected into the nidus under continuous visual control using biplane fluoroscopy.

As soon as reflux was noted along the microcatheter or early embolization of a draining vein was evident, the injection was stopped for 2 minutes and then resumed.

The maximum reflux to be treated was 2 $\mathrm{cm}$. The microcatheter was removed using one technique of gradual increase in traction. Staged sessions were planned for partially occluded AVMs.

\section{Postprocedural assessment:}

- Postmebolization size as detected by IA-DSA by the end of the procedure with comparison by baseline IA-DSA done before procedure.

- Immediate post-embolization angioarchitectural changes.

- Immediate neurological assessment.

- Data collected as regard total ICU stay or total ward stay.

- Symptomatic improvement as regard presenting symptom.

- Postprocedural complications.

- Procedure-related permanent morbidity and mortality.

- Radiological follow up by IA-DSA and repeated scoring or Spetzler-Martin AVMS grading system were done within 6 months after embolization. 
Table (1): Spetzler-Martin grading system (I-V) (Spetzler and Martin, 1986)

\begin{tabular}{ll}
\hline \multicolumn{1}{c}{ AVMS features } & Point \\
\hline Size of nidus & 1 \\
\hline Small $(<3 \mathrm{~cm})$ & 2 \\
\hline Medium $(3-6 \mathrm{~cm})$ & 3 \\
\hline Large $(>6 \mathrm{~cm})$ & \\
\hline $\begin{array}{l}\text { Eloquence } \\
\text { adjacent brain }\end{array}$ & 0 \\
\hline No eloquent & 1 \\
\hline Eloquent & 0 \\
\hline Venous drainage & 1 \\
\hline Superficial & \\
\hline Deep &
\end{tabular}

The assigned grade equals the sum of the points for all three features.

Grade I = Score 1

Grade II = Score 2

Grade III $=$ Score 3

Grade IV $=$ Score 4

Grade V = Score V

Statistical analysis:

The data were analyzed by using Statistical Package for Social Science (SPSS) program version 8, 1998. The qualitative data were presented in the form of numbers and percentage. $\mathrm{Z}$ value of Wilcoxon signed ranks test and paired $\mathrm{t}$ test were used as tests of significance. Significance was considered when $p$ value was less than 0.05 .

\section{RESULTS}

The mean age in our study was 34.32 years with range of 16-58 years and the standard deviation was 11.14 years. The sex distribution showed slight higher incidence in males $(56 \%)$ than in females (44\%) (table 2).

In our study, 10 patients (40\%) were presented with weakness due to Intracranial Hemorrhage (ICH), 7 patients $(28 \%)$ with epilepsy, 6 patients $(24 \%)$ with headache and 2 patients with weakness as a focal neurological deficit (8\%) (table 3).

The Spetzler and Martin grading of the cerebral AVMs before embolization was grade II in 3 patients (12\%), grade III in 15 patients $(60 \%)$, grade IV in 5 patients (20\%) and grade V in 2 patients $(8 \%)$ (table 4$)$.

The majority of patients received 2-3 sessions of Onyx injection with a total number of 67 sessions (table 5).

There was marked reduction in nidus diameter after embolization in which only one patient $(4 \%)$ had nidus diameter $>3 \mathrm{~cm}$ while 19 patients $(76 \%)$ had nidus diameter $\leq 3 \mathrm{~cm}$ (table $6)$.

There was significant difference in nidus diameter in all patients after embolization in comparison to before embolization $(\mathrm{p}=0.000)$ (table 7).

There was significant difference in Spetzler and Martin grading system before and after embolization $(\mathrm{p}=0.000)$ (table 8$)$.

Table (2): Age and sex distribution

\section{Age (years)}

\begin{tabular}{lcc}
\hline & Mean \pm SD & $34.32 \pm 11.14$ \\
\hline Sex & Range & $16-58$ \\
\hline & Male & $14(56 \%)$ \\
\hline & Female & $11(44 \%)$ \\
\hline
\end{tabular}

$\mathrm{SD}=$ Standard Deviation

Table (3): Clinical presentation of cerebral AVMs in our study

\begin{tabular}{lccc}
\hline & Clinical presentation & No & \% \\
\hline Weakness (ICH) & 10 & 40 \\
\hline Epilepsy & 7 & 28 \\
\hline Headache $\quad$ Total & 6 & 24 \\
\hline Weakness (focal neurological deficit) & 25 & 8 \\
\hline
\end{tabular}

ICH = Intracranial Hemorrhage 
Table (4): Spetzler and Martin classification of the cerebral AVMs before embolization in our study

\begin{tabular}{lccc}
\hline & Spetzler and Martin grading system & No & $\%$ \\
\hline Grade II & 3 & 12 \\
\hline Grade III & 15 & 60 \\
\hline Grade IV & 5 & 20 \\
\hline Grade V & 2 & 8 \\
\hline Total & 25 & 100 \\
\hline
\end{tabular}

Table (5): Number of sessions in our study

\begin{tabular}{cccc}
\hline & Number of sessions & No & \% \\
\hline 1 & 2 & 8 \\
\hline 2 & 9 & 36 \\
\hline 3 & 9 & 36 \\
\hline Total & 5 & 5 & 20 \\
\hline
\end{tabular}

Table (6): Nidus diameter of cerebral AVMs after embolization in our study

\begin{tabular}{lccc}
\hline & Nidus diameter & No & \% \\
\hline$>\mathbf{3} \mathbf{~ c m}$ & 1 & 4 \\
\hline$\leq \mathbf{3} \mathbf{~ c m}$ & 19 & 76 \\
\hline Total & 20 & 80 \\
\hline
\end{tabular}

Table (7): Nidus diameter before and after embolization in our study

\begin{tabular}{|c|c|c|c|c|c|c|}
\hline Nidus diameter & $\underset{\text { emb }}{I}$ & tion & After & ization & Test of significance & p value \\
\hline \multirow[t]{2}{*}{ Mean \pm SD } & \multicolumn{2}{|c|}{$4.2 \pm 0.8775$} & \multicolumn{2}{|c|}{$1.248 \pm 0.8554$} & \multirow[t]{2}{*}{ Paired $t$ test $=26.156$} & \multirow{4}{*}{$0.000^{*}$} \\
\hline & No & $\%$ & No & $\%$ & & \\
\hline$\leq 3$ & 3 & 12 & $24^{+}$ & $96^{++}$ & \multirow{2}{*}{$\begin{array}{c}\mathrm{Z} \text { value of Wilkoxon } \\
\text { signed ranks test }= \\
4.89\end{array}$} & \\
\hline$>\mathbf{3}$ & 22 & 88 & 1 & 4 & & \\
\hline
\end{tabular}

$\mathrm{SD}=$ Standard Deviation

*Significant $(\mathrm{p}<0.05)$

${ }^{+}$Five cerebral AVMs were completely occluded, while 19 cerebral AVMs had nidus diameter $\leq 3 \mathrm{~cm}$.

${ }^{++} 20 \%$ of the cerebral AVMs were completely occluded. 
Table (8): Spetzler and Martin grading of the cerebral AVMs before and 6-month follow up after embolization

\begin{tabular}{|c|c|c|c|c|c|c|}
\hline \multirow{2}{*}{ Spetzler and Martin grading } & \multicolumn{2}{|c|}{$\begin{array}{c}\text { Before } \\
\text { embolization }\end{array}$} & \multicolumn{2}{|c|}{$\begin{array}{c}\text { After } \\
\text { Embolization } \\
\end{array}$} & \multirow{2}{*}{$\mathrm{Z}$ value } & \multirow{2}{*}{$\mathbf{p}$} \\
\hline & No & $\%$ & No & $\%$ & & \\
\hline Grade I & 0 & 0 & 0 & 0 & \multirow{6}{*}{4.4} & \multirow{6}{*}{$0.000 *$} \\
\hline Grade II & 3 & 12 & 20 & 80 & & \\
\hline Grade III & 15 & 60 & 0 & 0 & & \\
\hline Grade IV & 5 & 20 & 0 & 0 & & \\
\hline Grade V & 2 & 8 & 0 & 0 & & \\
\hline Complete occlusion & 0 & 0 & 5 & 20 & & \\
\hline Total & 25 & 100 & 25 & 100 & & \\
\hline
\end{tabular}

$*$ Significant $(\mathrm{p}<0.05)$

\section{DISCUSSION}

As regards age and sex distribution, the mean age of the patients in our study was 34.32 years with range of $16-58$ year and standard deviation as 11.14 years with higher incidence in males $(56 \%)$ than in females $(44 \%)$, this approximately goes with the results performed on a number of 89 patients with arteriovenous malformations, which reported that $54(60.67 \%)$ were males and $35(39.32 \%)$ were females. The age distribution recorded incidence peaks in the $3^{\text {rd }}$ and $4^{\text {th }}$ decade $^{(\mathbf{9})}$.

In support to our study, Hofmeister et al. ${ }^{(10)}$ reported that the mean age at diagnosis is 31.2 years, $45 \%$ of the patients are females and the cerebral AVMs are occasionally seen in the elderly but are typically diagnosed before the patient has reached the age of 40 years.

With our study, another study proved that AVMs present usually before 40 years, despite that they found in contrast to us that AVMs affect females and males equally ${ }^{(\mathbf{1 1})}$.

Regarding the presentation of the cerebral AVMs in our study, $40 \%$ were presented with weakness due to intracerebral hemorrhage, $28 \%$ with epilepsy, $24 \%$ with headache and $8 \%$ with weakness due to AVM itself. This result goes in hand with many studies. Data from international databases and prospective population-based studies suggest that more than half of all arteriovenous malformations patients may suffer intracranial hemorrhage ${ }^{(\mathbf{1 1})}$.

Also, in agreement with our study, Ondra et al. (12) demonstrated that intracranial hemorrhage was also the most common recorded type of AVMs presentation, between $17 \%$ and $40 \%$ of the patients with AVMs presented with epileptic seizures. Headache was the third presentation, approximately $1 \%$ to $10 \%$ of patients with cerebral AVMs presented initially with headaches.

On the contrary, Jizong et al. ${ }^{(13)}$ proved that headache was the second common presentation following the intracranial hemorrhage and seizure was the third common presentation accounting for about $17.3 \%$.

The Spetzler and Martin classification of cerebral AVMs among the studied patients was grade II in 3 patients (12\%), grade III in 15 patients $(60 \%)$, grade IV in 5 patients $(20 \%)$ and grade $\mathrm{V}$ in 2 patients (8\%).

This disagrees to some extent with Weber et al. $^{(7)}$ who found in their series of 47 patients that 25 patients were grade I or II, 10 patients were grade III and 12 patients were grade IV or V.

In this work, 67 sessions of Onyx injection were done to all patients, the majority of patients received 2-3 sessions. The rate of total occlusion of brain AVMs with embolization was $20 \%$ (5 patients).

There was marked reduction in nidus diameter after embolization in which only one patient had nidus diameter $>3 \mathrm{~cm}$ while 19 patients $(76 \%)$ had nidus diameter $\leq 3 \mathrm{~cm}$. There was significant difference in nidus diameter in all patients after embolization in comparison to before embolization $(\mathrm{p}=0.000)$.

The Spetzler and Martin grading of the cerebral AVMs was grade II in patients with partial oclcusion (20 patients). There was 
significant difference in Spetzler and Martin grading system after embolization in comparison to before embolization $(p=0.000)$.

These post-embolization results are similar to that obtained by van Rooij et al. ${ }^{(14)}$ who reported a series of patients undergoing embolization with Onyx, observing a cure rate of $16 \%$ (7 patients), Weber et al. ${ }^{(7)}$ who reported a complete obliteration rate of $20 \%$ alone in a series of 94 cases. Two recurrences were present at 3month follow-up angiographic examination, resulting in a complete obliteration rate of $18 \%$, Katsaridis et al. ${ }^{(15)}$ who demonstrated substantially higher cure rates in a consecutive series of 101 patients. Among the 101 patients, there were 52 patients in whom the treatment was completed; 28 (53.9\%) AVMs were totally occluded by endovascular procedure alone, Pangiotopoulos et al. $^{(16)}$ who observed a complete initial occlusion of 20 patients $(24.4 \%)$ in 82 cases whereas the complete obliteration rate was $19.5 \%(16 / 82)$ and Xu et al. ${ }^{(\mathbf{1 7 )}}$ who reported in a series consisting of 86 patients that complete occlusion was $18.6 \%(16 / 86)$ and partial occlusion was achieved in $81.4 \%$ (70/86).

Our results seem to indicate that curative embolization of AVMs can achieve high rates of total and near total occlusion with acceptable complications.

\section{CONCLUSION}

The endovascular treatment of the cerebral AVMs is safe, efficient and can achieve high rates of total and near total occlusion. Onyx as a new embolic material, with its non-adherent properties has significantly facilitated this development.

\section{REFERENCES}

1- Koenigsberg RA, Smirniotopoulos JG, Diegnan BR, Wasserman JR and Levy LM (2011): Brain imaging in arteriovenous malformation. Eur Radiol; 20(11): 2723-2731.

2- Mounayer C, Hammami N and Piotin M (2007): Nidal embolization of brain arteriovenous malformations using Onyx in 94 patients. Am J Neuroradiol; 28(3): 518-523.

3- Spetzler RF and Martin NA (1986): A proposed grading system for arteriovenous malformations. J Neurosurg; 65(4): 476-483.

4- Santos ML, Junior ZD, Matos LA, Spotti AR, Tognola WA, de Sousa AA and dos Santos RM (2009): Angioarchitecture and clinical presentation of brain arteriovenous malformations. Arq. NeuroPsiquiatr.; 67(2): 316-321.
5- Walcott BP, Gerrard JL, Nogueira RG, Nahed BV, Terry AR and Ogilvy CS. Microsurgical retrieval of an endovascular microcatheter trapped during Onyx embolization of a cerebral arteriovenous malformation. J Neurointervent Surg 2011; 3: 7779.

6- Richling B and Killer M. Endovascular management of patients with cerebral arteriovenous malformations. Neurosurg Clin N Am 2000; 11(1): 123-145.

7- Weber W, Kis B, Siekmann R, Jans P, Laumer R and Kuhne D. Preoperative embolization of intracranial arteriovenous malformations with Onyx. J Neurosurg 2007; 61(2): 244-254.

8- Sobh K and Hegazy A. Feasibility and outcomes of endovascular embolization of cerebral arteriovenous malformations at a low volume center. J Vasc Interv Neurol 2013; 5(2): 4-8.

9- Dãnãlla L (2012): Malformations in the temporal lobe: Microsurgical treatment and results in 89 cases. Proc. Ron. Acad.; 14(3): 196-206.

10- Hofmeister C, Stapf C, Hartmann A, Sciacca RR, Lasjaunias P, Mohr JP, Mast $\mathrm{H}$ and Meisel J. Demographic, morphological, and clinical characteristics of 1289 patients with brain arteriovenous malformation. Stroke 2000; 31(6): 1307-1310.

11- ApSimon HT, Reef H, Phadke RV and Popovic EA. A population-based study of brain arteriovenous malformation: Long-term treatment outcomes. Stroke 2002; 33(12): 2794-2800.

12- Ondra SL, Troupp H and George ED (1990): The natural history of symptomatic arteriovenous malformations of the brain: A 24-year follow-up assessment. J Neurosurg; 73(3): 387-396.

13- Jizong Z, Shuo W, Jingsheng L, Wei Q, Dali S and Yuanli Z. Clinical characteristics and surgical results of patients with cerebral arteriovenous malformation. J. Neurosurg. 2005; 63(2): 156-161.

14- Van Rooij WJ, Sluzewski $M$ and Beute GN. International arteriovenous malformation with Onyx. Am J Neuroradiol 2007; 28: 172-177.

15- Katsaridis V, Papagiannaki C and Aimar E. Curative embolization of cerebral Arteriovenous Malformations (AVMs) with Onyx in 101 patients. Am J Neuroradiol 2008; 50: 589-97.

16- Pangiotopoulos V, Gizewski E, Asgari S, Regel J, Forsting $\mathrm{M}$ and Wenke I. Embolization of intracranial arteriovenous malformations with ethylene-vinyl alcohol copolymer (Onyx). Am J Neuroradiol 2009; 30: 99-106.

17- Xu F, Ni W, Liao Y, Gu Y, Xu B, Leng B and Song D. Onyx embolization for the treatment of brain arteriovenous malformations. Acta Neurochir 2011; 153: 869-878. 


\section{انصمام التثوهات الثريانية الوريدية المخية}

تتكون التشوهات الثريانية الوريدية المخية من تجمعات مركبة من الأوعبة الدموية التى تتغذى عن طريق شريان أو أكثر ويتم صرفها وريدياً عن

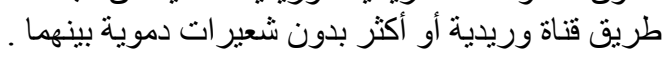

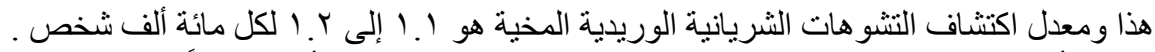

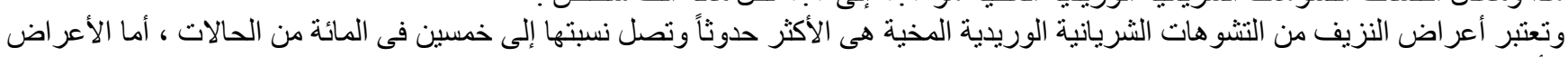

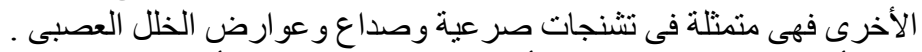

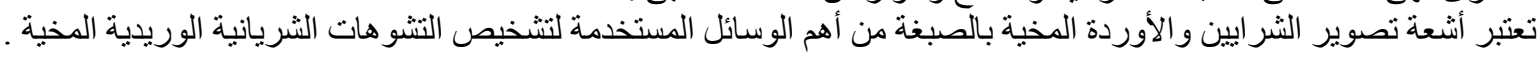

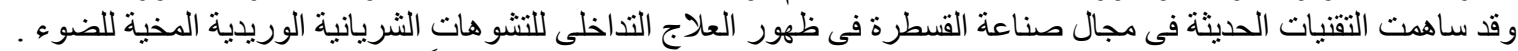
ويهدف انصمام التشو هات الثريانية الوريدية المخية باستخدام القسطرة إلى غلقها غلقا كاملاً أو تضييق حجمها من أجل تسهيل التدخل الجر احثى أو الورية

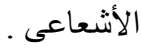

الهذف من البحث هو تقييم فاعلية العلاج التداخلى للتشوهات الثريانية الوريدية المخية . اشتملت هذه الدر اسة على عدد خمسة وعشرين مريض فريضاً بالتشوهات الثريانية الوريدية المخية بعد أخذ مو افقة كتابية من المرضى تم إجر اء الآتى لهم

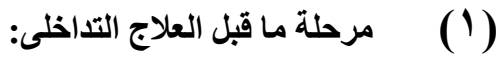

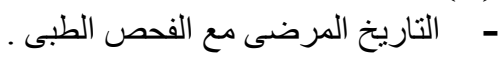

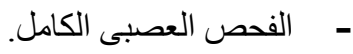
- تحاليل معملية وتثمل: صورة دم كاملة ودلالات زمن تخثر الدم ونسبة اليوريا نيتروجين والكرياتينين بالدم ودلالات الفيروسات الكبدية بى - أنثعة مقطعية أو رنين مغناطيسى على المخح.

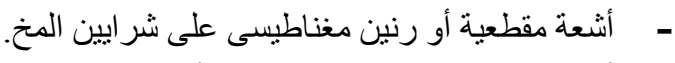
-

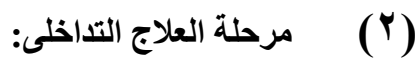
- تحديد عدد الجلسات. ـ التغير الثكلى و الحجمى فى التشو هات الثريانية الوريدية المخية بعد عملية الانصمام مباثرةً.

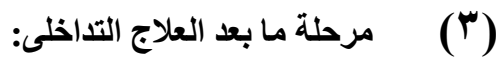

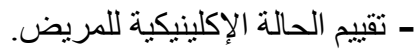

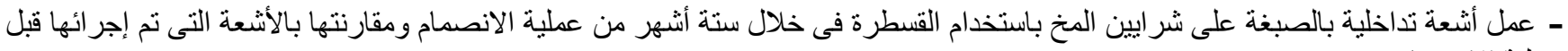
عملية الانصمام.

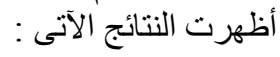

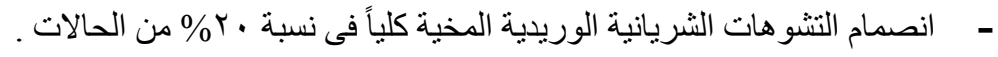

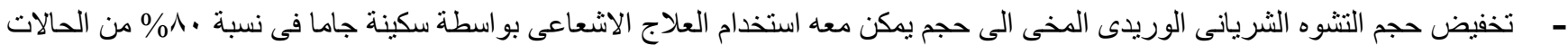
لقد خلصنا من هذه الدراسة أن انصمام التشوهات الثريانية الوريدية المخية باستخدام مادة الأونكس آمن وفعال ويؤدى إلى انصمام التشوهات

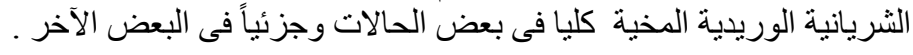

